Harika Öykü Dinç $\odot$ Doğukan Özbey $\odot$

Serhat Sirekbasan $\oplus$

Nesrin Gareayaghi ๑

Bekir S. Kocazeybek $\odot$

\title{
Seroepidemiologic Evaluation of HIV Scanning and Verification Datas During The Period of 2015-2018
}

Öz

Ocak 2015-Aralık 2018 yılları arasında Istanbul Üniversitesi-Cerrahpaşa Cerrahpaşa Tıp Fakültesi Tıbbi Mikrobiyoloji Merkez Laboratuvarı Seroloji/ELISA Birimi'ne; ameliyat öncesi serolojik tarama amacıyla ya da HIV enfeksiyonu şüphesiyle başvuran olguların retrospektif olarak HIV tarama ve doğrulama test sonuçlarının demografik verileri ile birlikte irdelenmesi amaçlanmıştır. Ayrıca merkezimizin bir önceki dönemine ait verileriyle HIV seroprevalansının karşılaştırılması amaçlanmıştır.

HIV-1/2 antikor+P24 antijen (HIV-1/2 Ab/Ag) rutin olarak ELISA yöntemiyle ve ikinci tekrar testi olarak kemilüminesans immunoassay (CLIA) yöntemi ile araștırılmıștır. HIV-Ab/Ag testi ile tekrarlayan reaktiflik saptanan serumların doğrulaması Line Immunoassay (LIA) yöntemiyle yapılmıștır.

Retrospektif olarak dört yıllık dönemde incelenen 144,256 olgunun 366'sında (\% 0.25) antiHIV-1/2 tekrarlayıcı reaktiflik gözlenmiştir. Tekrarlayan reaktiflik gösteren serum örneklerinden, daha önce doğrulanmış olanlar hariç tutularak 180 serum örneğinde doğrulamak amacı ile LIA testi çalısılımış ve 158 (\% 87.8)'inde pozitiflik saptanmıştır. Bu örneklerin tamamında sgp120 ve gp41 bant pozitifliği ile HIV-1 olduğu doğrulanmıştır.

Merkezimizden dört yıllık dönemde retrospektif olarak elde ettiğimiz HIV seroprevalans sonuçları, ülkemizden bildirilen diğer çalışmalarınkine yakın oranlarda bulunmuştur. istanbul gibi kozmopolit ve göç alabilen bir bölgedeki HIV artış oranı, merkezimizden bir önceki döneme ait elde edilen \% 0.06 prevalans oranına kıyasla daha yüksek bulunmuştur.

Anahtar kelimeler: Anti-HIV, LIA, ELISA, HIV-1, HIV-2

\section{ABSTRACT}

The aim of this study is to retrospectively discuss the patients' HIV scanning and verification test results along with their demographics, who were admitted to Istanbul UniversityCerrahpaşa Cerrahpaşa Medical Faculty Medical Microbiology Laboratory Center Serology/ ELISA division with the suspicion of HIV infection or pre-op serologic scanning. In addition, we aimed to compare HIV seroprevalence with the data of the previous period of our center.

HIV-1/2 antibody $+P 24$ antigen (HIV -1/2 Ab/Ag) was studied routinely with ELISA method, and as a second repeat test chemiluminescence immunoassay (CLIA) method was used. The verification of the patient sera, which showed repetitive reactivity after HIV -Ab/Ag test, was studied with line immunoassay (LIA) method.

Retrospectively, in the 144,256 cases which was studied in the past 4 years, there were 366 $(0.25 \%)$ anti HIV-1/2 repeated reactivity. From repeated reactivity serum samples, LIA testing was performed to confirm 180 serum samples, excluding those previously confirmed, and 158 (87.8\%) were positive. All of these specimens showed sgp120 and gp41 band positivity, therefore HIV1 positivity was confirmed.

These retrospective data from one center on HIV seroprevalence for a 4-year period are in agreement with other Turkish studies. Rate of HIV prevalence in Istanbul, which is a cosmopolit and immigrant receiving city, was found to have increased compared to the last period of time, which was only $0.06 \%$.

Keywords: Anti-HIV, LIA, ELISA, HIV-1, HIV-2
Alındığı tarih: 24.04 .2019

Kabul tarihi: 03.09.2019

Yayın tarihi: 30.12 .2019

Harika Öykü Dinç

istanbul Okan Üniversitesi Tıp Fakültesi, Tuzla Kampüsü, Akfirat, Tuzla İstanbul - Türkiye

oykudinc@gmail.com ORCID: 0000-0003-3628-7392

D. Özbey 0000-0002-0596-1551 B. S. Kocazeybek 0000-0003-1072-3846 Istanbul Üniversitesi Cerrahpaşa Cerrahpaşa Tıp Fakültesi, Tıbbi Mikrobiyoloji Anabilim Dalı Istanbul - Türkiye

S. Sirekbasan 0000-0001-7967-3539 Cankırı Karatekin Üniversitesi Eldivan Sağlık Hizmetleri Meslek Yüksekokulu Tıbbi Laboratuvar Teknikleri Bölümü Çankırı - Türkiye

N. Gareayaghi 0000-0002-0812-1128 istanbul Şişli Hamidiye Etfal Eğitim ve Araștirma Hastanesi, Kan Merkezi istanbul - Türkiye 


\section{Giriş̧}

Human Immunodeficiency Virus (HIV) konak hücre DNA'sına yerleşen retrovirus ailesine ait bir RNA virüsüdür. Klinik olarak immün supresyona neden olur ve akut retroviral sendromdan başlayarak kazanılmış immün yetmezlik sendromuna (Acquired immunodeficiency syndrome, AIDS) ilerleyebilen tablolar zemininde fatal seyredebilen fırsatçı enfeksiyonlar ve malignitelerin gelişimi ile sonuçlanabilir(6). Ancak HIV, güncel anti-retroviral tedaviler sayesinde günümüzde ölümcül bir hastalık etkeni olmaktan çıkıp yönetilebilir kronik bir enfeksiyon hastalığına dönüşmüştür. Bu nedenle HIV pandemisi ile mücadelede en temel unsur; enfekte kişilerin en kısa sürede tanısının yapılması ve yüksek aktiviteli anti-retroviral tedaviye (HAART) başlamasını sağlamaktır. Tarihsel olarak değerlendirildiğinde, HIV pandemisinin gelişiminde kentsel yaşam ve endüstrileşmeye bağlı kırsal kesimden başlayan ve giderek artan göç hareketlerinin yarattığı şehirleşmenin, toplumsal yaşamda korunmasız seksüel ilişkilerin ve kan/kan ürünleri ile bulaşmaya zemin hazırlayan invaziv tıbbi girişimlerin yaygınlaşmasının rol oynadığı görülmektedir. Bu anlamda politik ve non-politik kırılmaların yarattığı sosyoekonomik ve sosyokültürel değişimlerin ülkemizde HIV seroprevalansını epidemiyolojik yönden etkilediği bilinen bir gerçek olup, bu tip pandemik enfeksiyon hastalıklarının belli dönemlerde izlenmesi önemli ve halk sağlığı yönünden çok yararlıdır. Bu çalışmada Ocak 2015-Aralık 2018 arasındaki dört yıllık dönemde anabilim dalımız seroloji/ELISA laboratuvarına HIV infeksiyonu kuşkusuyla ya da ameliyat öncesi serolojik tarama amacıyla Anti-HIV 1-2 testi yaptırmak üzere başvuran ya da kanları gönderilen olguların ELISA ve Line Immunoassay (LIA) test sonuçlarının demografik veriler birlikte retrospektif olarak irdelenmesi amaçlanmıştır. Ayrıca bu dönem elde edilen veriler bir önceki dönem (Eylül 2004-Aralık 2009) verileriyle karşılaştırılarak HIV enfeksiyonu seroprevalansı değerlendirilmiştir.

\section{GEREÇ VE YÖNTEM}

Çalışmamız retrospektif olarak planlanmış, Ocak 2015-Aralık 2018 tarihleri arasında çeşitli kliniklerden operasyon öncesi tarama veya klinik şüphe üzerine Anti-HIV serolojisi çalışııması için gönderilen örneklerin sonuçları değerlendirilmiştir. Hastaların demografik verileri geriye dönük olarak ìstanbul Üniversitesi- Cerrahpaşa, Cerrahpaşa Tıp Fakültesi Hastanesi'nin isHOP Doktor ve Laboratuvar Bilgilendirme Sistemi'nden elde edilmiştir. Serum örneklerinde ELISA yöntemiyle HIV 1-2 Antikor+p24 Antijen (EIAgen Detect HIV 4 Total Screening Kit, Adaltis, İtalya) varlığı araştırılmıştır. Üretici firma önerileri doğrultusunda çalışılan testte reaktif saptanan serum örnekleri aynı yöntem ile ikinci kez tekrarlanmıştır. Çıkan sonuçların birimi (S/CO [signal/ cut-off]) olarak kaydedilmiştir. Her iki çalışma sonucunda da tekrarlayan reaktiflik saptanan hastalardan ikinci kez kan alınmış ve kemilüminesans immunoassay (CLIA) yöntemi ile HIV 1-2 Antikor+p24 Antijen testi (The Elecsys ${ }^{\circledR}$ HIV combi PT, Roche, Almanya) uygulanmıştır. Tekrarlayan reaktif örnekler doğrulama testi olarak Line Immunoassay (LIA) (INNO-LIA ${ }^{\circledR}$ HIV I/II Score, Immunogenetics, Almanya) ile çalışılmıştır. Centers for Disease Control and Prevention $(C D C)$ ve World Health Organization (WHO) önerileri doğrultusunda en az iki zarf protein bandı (sgp120/gp41 veya sgp105, gp36) veya en az bir zarf protein bandı (sgp120/gp41 veya sgp105, gp36) ile birlikte p24 antijen bandı varlığının olması WB/LIA testinde tanıyı doğrulayıcı kriter olarak kabul edilmiştir ${ }^{(1,5,13)}$. Belirtilenler dışında bantların saptanması belirsiz ("indeterminate"), bant yokluğu ise negatif olarak kabul edilmiştir. Elde edilen veriler "SPSS 21" programı kullanılarak analiz edilmiştir. Sonuçların istatistiksel değerlendirilmesi için tanımlayıcı istatistiksel analizlerin (frekans, yüzde) yanı sıra Ki-Kare testi kullanılmıştır.

\section{BULGULAR}

Retrospektif değerlendirmede 144,256 AntiHIV 1-2 test istemi yapılmış olup, çeşitli nedenlerden 
Tablo 1. HIV-1/2 tekrarlayan reaktivite gösteren hastaların yaş ve cinsiyete göre dağılımı.

\begin{tabular}{lcr}
\hline & \multicolumn{2}{c}{ Cinsiyet (n) } \\
\cline { 2 - 3 } Yaş Grupları & Kadın & Erkek \\
\hline $0-14$ & 3 & 7 \\
$15-24$ & 3 & 57 \\
$25-49$ & 37 & 186 \\
$>50$ & 15 & 58 \\
\hline Toplam & 58 & 308 \\
\hline
\end{tabular}

dolayı 2,838 hastanın serumları birimimize ulaşamamıştır. Dört yıllık dönemde incelenen 141,418 serum örneklerinin \% 0.25 'inde ( $n=366)$ HIV 1-2 Antikor+p24 Antijeni açısından tekrarlayan reaktiflik saptanmıştır. Bu 366 hastanın \% 84.2'si (n=308) erkek ve $\% 15.8^{\prime} i(n=58)$ kadın olup, her yaş grubundan hasta olmakla birlikte yaşortalaması 37.31 olarak bulunmuştur (Tablo 1, Şekil). Anti-HIV tekrarlayan reaktif saptanan kişilerin 13'ü (\% 3.55) 18 yaş altındadır.

Tanı/tedavi sürecinin hastaya bağlı olarak yarıda bırakılması ya da daha önceden doğrulama testinin yapılmış olması gibi çeşitli nedenlerden dolayı tekrarlayan reaktiflik gösteren 186 hastaya doğrulama testi isteği yapılamamıştır. Bu nedenle tekrarlayan reaktiflik gösteren hastaların yalnızca 180'inde (\% 49.2) doğrulamak amacıyla Line Immunassay (LIA) testi çalışılabilmiştir. Bu hastaların $158^{\prime}$ inde (\% 87.8)
Tablo 2. Yıllara göre HIV enfeksiyonu sıklığı.

\begin{tabular}{lccc}
\hline Tanı yılı & $\begin{array}{c}\text { Toplam Hasta } \\
(\mathbf{n})\end{array}$ & $\mathbf{n}$ & HIV (+) \\
\hline Ocak-Aralık 2015 & 29,568 & 52 & 0.17 \\
Ocak-Aralık 2016 & 33,700 & 46 & 0.13 \\
Ocak-Aralık 2017 & 38,460 & 32 & 0.08 \\
Ocak-Aralık 2018 & 39,690 & 28 & 0.07 \\
\hline Toplam & 141,418 & 158 & 0.11 \\
\hline
\end{tabular}

pozitiflik saptanırken, 22'si (\% 12.2) negatif bulunmuştur. HIV-1 yönünden LIA pozitifliği 157 (\% 99.4) olguda saptanmış, bir olguda hem HIV-1 (sgp120/gp41) hem HIV-2 (gp36) band reaktifliği gözlenmiş, tek başına HIV-2 pozitifliği görülmemiştir. HIV-1/2 dual (mikst) enfeksiyon gösterilen olgu hem Genius HIV-1/2 testi ile hem de HIV-1 RNA testi ile HIV-1 pozitif bulunurken, HIV-2 proviral DNA negatif saptanmıştır. Bulaş yolları incelendiğinde LIA pozitif olan 158 olgunun 49'unda (\% 31.0) heteroseksüel ilişki, 41'inde (\% 25.9) homoseksüel ilişki, ikisinde (\% 11.4) parenteral uyuşturucu kullanımı ve beşinde (\% 13.3) de diş tedavisi öyküsü alınmıştır. Olguların 29'unda (\% 18.4) olası bulaşma yoluna ilişkin bilgi alınamamıştır. Seropozitif bant dağılımları incelendiğinde 121 kişide (\% 76.6) sgp120, gp41, p31, p24, p17 bantlarının birlikte pozitif olduğu saptanmıştır (Tablo 3).

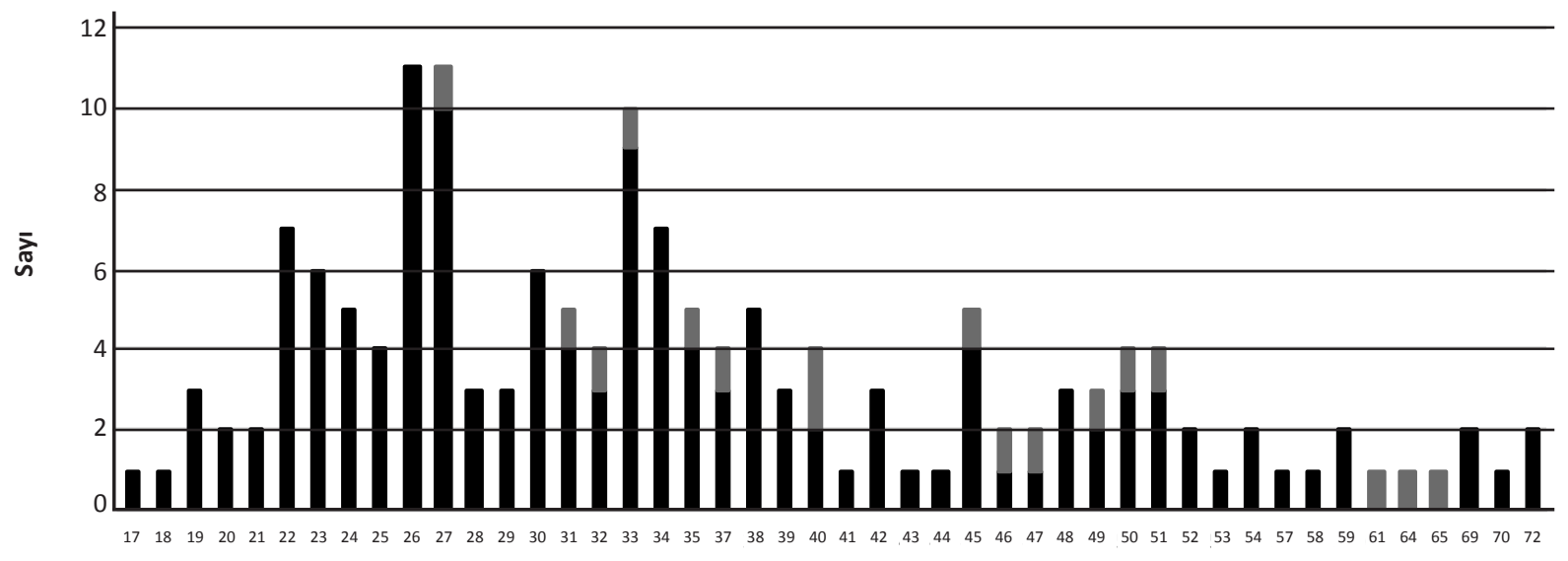

Yaş 
Tablo 3. LIA ile pozitif saptanan HIV-1/2 enfekte olgularda reaktif saptanan spesifik bantların dağııımı.

\begin{tabular}{lrr}
\hline Bantlar & $\mathbf{n}$ & $\%$ \\
\hline HIV-1 & & \\
Sgp 120, gp41, p31, p24, p17 & 121 & 76.6 \\
Sgp 120, gp41, p31, p24 & 5 & 3.2 \\
Sgp 120, gp41, p24, p17 & 6 & 3.8 \\
Sgp 120, gp41, p31, p17 & 5 & 3.2 \\
Sgp 120, gp41, p24 & 7 & 4.4 \\
Sgp 120, gp41, p31 & 1 & 0.6 \\
gp41, p31, p24 & 4 & 2.5 \\
gp41, p24 & 7 & 4.4 \\
Sgp 120, gp41 & 1 & 0.6 \\
HIV-1 + HIV-2 & & \\
Sgp120,gp41 + gp36 & & \\
\hline
\end{tabular}

HIV doğrulama sonucu pozitif olan 158 kişinin yaş dağılımı 17-72 arasında olup, ortalaması 36.01 olarak bulunmuştur. Tekrarlayan reaktiflik gösteren hastaların LIA pozitifliği yönünden yaşa göre dağılımına bakıldığında istatistiksel olarak anlamlı fark saptanmamasına karşın, HIV enfeksiyonu en sık 24-35 yaş grubu arasında görülmektedir. Onsekiz yaş altı iki olgu bulunmakta olup, bulaş yolu homoseksüel ilişkidir (Tablo 2). Enfekte olguların \% 89.2'i (141) erkek, \% 10.8'i (17) kadındır. Cinsiyetler arasında pozitiflik oranı istatistiksel olarak incelendiğinde, erkeklerdeki yükseklik anlamlı bulunmuştur $(\mathrm{p}<0.05)$. Tanı yılına göre HIV seropozitif olguların sıklığına bakıldığında en yüksek oran 2015 te (\% 0.17) görülmüştür. Yıllara göre HIV pozitiflik oranları Tablo 2'de verilmiştir.

\section{TARTIŞMA}

1980 yılında ABD'deki ilk beş olgunun ardından başlayan HIV pandemisi 2000'li yıllara kadar artmış olup, kontrol altına almak için yapılan çalışmalar sonuç vererek 2010 yılı itibarıyla yeni HIV enfeksiyonlarının sayısında \% 16 azalma sağlanmışıır ${ }^{(12)}$. Buna karşın; Avrupa ülkelerinde artış görülmekle birlikte, özellikle ülkemizin de içinde bulunduğu Orta Avrupa bölgesinde 2005-2014 yılları arasında yeni enfeksiyon oranı \% 115 artmışıı ${ }^{(3)}$. WHO 2017 verilerine göre dünya genelinde 36.9 milyon insan HIV ile enfektedir ve bu kişilerin 1.8 milyonu son bir yıl içinde tanımlanmış yeni olgulardır ${ }^{(14)}$.
Ülkemizde ilk bildirim tarihinden 01 Kasım 2018'e kadar 18,557 HIV seropozitif kişi ve 1,736 HIV/AIDS olgusu bildirilmiştir. Özellikle dikkati çeken, 2011 yılında 673 kişi HIV ile enfekte iken, 2017 yılında bu sayının dört katından fazla artış göstermesi ve HIV pozitif kişi sayısının 3,029'a ulaşması olmuştur ${ }^{(11)}$. Her ne kadar ülkemizde HIV enfeksiyonu Avrupa, Kuzey Amerika, Uzak Doğu Asya ve Afrika ülkelerine kıyasla çok daha az olsa da toplumun tüm kesimini etkileyen ciddi bir halk sağlığı problemi olarak karşımıza çıkmaktadır.

Beş yıllık dönemde Türkiye Yüksek Ihtisas Eğitim ve Araştırma Hastanesi Transfüzyon Merkezi'ne başvuran 28,026 donörün 17 (\% 0.06)'sinde Anti-HIV reaktifliği saptanmış ancak, "western blot" ile doğrulaması yapılmamıştır(9). Yine bir başka kan merkezinde yapılan bir çalışmada ise, 2009-2013 yılları arasında 45,632 donörün yalnızca ikisinde (\% 0.004) Anti-HIV reaktifliği saptanmış ve yalnızca biri "western blot" ile doğrulanmıştır ${ }^{(7)}$. Ankara Numune Hastanesi'nde 2012 yılında çeşitli poliklinik ve servislerden gönderilen 57,247 serum örneğinde Anti-HIV reaktifliği 50 kişide (\% 0.087 ) tespit edilmiştir $^{(4)}$. 2005-2015 yılları arasında İstanbul Tıp Fakültesi Tıbbi Mikrobiyoloji Laboratuvarı'na çeşitli kliniklerden tarama amaçlı gönderilen 146,055 serum örneğinin 600'ünde ELISA yöntemi ile Anti-HIV reaktivitesi saptanmıştır. Bu olguların 321'i “western blot" ile HIV-1 yönünden doğrulanmış, \% 76'sının erkek \% 24'ünün kadın hastalardan oluştuğu görülmüştür. Bulaş yolları incelendiğinde sırasıyla en sık heteroseksüel cinsel ilişki (\% 53.3), homoseksüel cinsel ilişki (\% 15.3) ve anneden bebeğe geçiş (\% 2.8) yoluyla olduğu saptanmıştır(2). T.C. Sağlık Bakanlığı Kasım 2018 verilerine göre ülkemizde HIV ile enfekte bireylerin \% 79.6'sının erkek olduğu ve \% 49.6'sının cinsel yolla bulaştığı ve cinsel yolla bulaştığı bildirilen bu vakaların \% 71'inin heteroseksüel cinsel ilişki olduğu bildirilmiştir. Ayrıca, vakaların \% 1.3'ünün bulaşma yolu damar içi madde kullanımından kaynaklanmıştır $^{(10)}$. Çalışma merkezimize ait daha önceki döneme ait yapılan bir çalışmada ise beş yıllık dönemde incelenen 84,164 serum örneğinin 72'sinde Anti-HIV 1-2 seropozitifliği saptanmış, "western blot" 
H.Ö. Dinç ve ark., İstanbul Üniversitesi-Cerrahpaşa Cerrahpaşa Tıp Fakültesi Hastanesi 2015-2018 Dönemi HIV Tarama ve Doğrulama Verilerinin Seroepidemiyolojik Değerlendirilmesi

yöntemiyle 56'sının (\% 0.06) HIV-1, bir olgunun da HIV-2 olduğu doğrulanmıştır. HIV-1 saptanan 56 kişi bulaş yolu açısından değerlendirilmiş, heteroseksüel cinsel ilişki (\% 62.5), homoseksüel cinsel ilişki (\% 7.14), damar içi madde (\% 3,5) kullanımı saptanmışırır ${ }^{(16)}$.

Çalışmamızda WB pozitif olguların HIV-1'le ilişkili seropozitif bant dağılımı incelendiğinde 158 kişinin 122'sinde (\% 77.2) Sgp 120, gp41, p31, p24, p17 saptanmıştır. Çalışma dönemimize ait HIV-2 olgusu olmasa da; özellikle küreselleşme, turizm, yoğun insan hareketlerini, göç ve artan seks işçiliğinin yansımalarından dolayı pandemi olarak nitelendirilen HIV-1 enfeksiyonun yanı sıra HIV-2 enfeksiyonlarının sıklığının artması dikkatten kaçmamalıdır. Bu çalışmada HIV-1 ve HIV-2 dual enfeksiyon şüpheli bir olgu olmakla birlikte, sonradan yapılan detaylı HIV$1 / 2$ immünokromotografik testler ve moleküler yöntemler (HIV-1 ve HIV-2 proviral DNA) ile olgu HIV-1 pozitif bulunmuştur. Dual enfeksiyonlar 1989 yılından 2010'lu yıllara kadar HIV-1/2 doğrulamasında ciddi bir tanısal problemdir. Bunlardan dolayı başta $A B D$ ve batı ülkeleri HIV-1/2 tanı algoritmasını değiştirmişlerdir. Algoritmada ilk aşamada dördüncü kuşak antijen/antikor (Ag/Ab) saptama amaçlı ELISA/ Kemilüminesans, sonrasında tekrarlayan reaktivitenin HIV-1/2 ayrımını (discrimination) yapan immünokromotografik prensipli yöntemle tanımlanması ve bu testte yine belirsiz sonuç alındığında HIV-1/2 nükleik asit testi (NAT) ile doğrulama öngörülmektedir. Bu algoritma Türkiye'de 2018 Temmuz ayında T.C. Sağlık Bakanlığı tarafından resmen kabul edilmiş olmakla birlikte, gebe kadınlar hariç şimdilik ekonomik nedenlerle kısıtlı olarak uygulanabilmektedir ${ }^{(11)}$. Nitekim, bu hususta ülkemizden 2018 yllında bildirilen ve merkezimizinde dahil olduğu çok merkezli bir çalışmada; WB/LIA test sonucunda HIV-1 bandı ile HIV-2'ye spesifik gp36 bandı saptanan dual enfeksiyon şüpheli 32 serum örneği detaylı bir başka HIV-1/2 immünokromotografik yöntem ile tekrar çalışılmış ve moleküler yöntemlerle virus HIV-1/2 RNA varlığ araştırılmiştir. Bunun sonucunda, dual enfeksiyon şüpheli olguların hiçbirinde HIV-2 bandı ve HIV-2 RNA'sı saptanamayarak, HIV-1 enfeksiyonu doğrulanmıştır ${ }^{(15)}$.
Dört yıllık dönemde retrospektif olarak elde ettiğimiz HIV seroprevalans sonuçları, ülkemizde çeşitli merkezlerde yapılan çalışmaların verilerine yakın oranlarda bulunmuştur. Merkezimizin HIV seroprevalansı Ocak 2006-Aralık 2009 dönem aralığında 0,06 bulunmuş olup, yıllar içinde iki kata yakın artış görülmektedir ${ }^{(7)}$. Her ne kadar ülkemizdeki HIV prevelansı uluslararası verilere göre düşük seyretse de, sayının daha fazla olduğu düşünülmektedir. Nitekim, Birleşmiş Milletler HIV/ AIDS Programı (UNAIDS) temsilcisi Martin Donoghue, Türkiye'deki HIV artış hızının \% 467 olduğunu ve bu artışa dayanarak 2028'de HIV ile yaşayan kişi sayısını 39,231 olarak öngördüklerini belirtmiştiir(8). Yüksek düzeyde kentleşmiş ve kültürel açıdan kozmopolit bir şehir olan İstanbul'da bir üniversite hastanesi olarak verilerimizin Türkiye literatürüne ve Türkiye kaynaklı uluslararası düzeyde toplum sağlığına katkı sağlayacağını düşünmekteyiz. Ciddi bir enfeksiyon hastalığı etkeni olan HIV'in yanlış pozitifliği veya negatifliği minimum olan ve erken dönemde tanıya olanak sağlayan uygun algoritmalarla tanısı epidemiyolojik açıdan önemlidir. HIV enfeksiyonlarının İstanbul gibi göç alan ve kentsel yaşamın yoğun ve karmaşık olduğu popülasyonlarda izleminin ciddi olarak yapılmasının ülkemizde korunma önlemlerinin alınmasına katkı sağlamanın yanı sıra, küreselleşen dünyada da halk sağlığı yönünden katkıları olacağına inanıyoruz.

Çıkar Çatışması: Yazarlar tarafından herhangi bir çıkar çatışması bildirilmemiştir.

Conflict of Interest: No conflict of interest was declared by the authors.

\section{KAYNAKLAR}

1. 1993 revised classification system for HIV infection and expanded surveillance case definition for AIDS among adolescents and adults. MMWR Recomm Rep. 1992;41(RR-17):1-19.

2. Beka H, Yılmaz M, Köksal MO, Meşe S, Eraksoy H, Somer A, Ağaçfidan A. Anti-HIV reaktif hastalarda doğrulama testi sonuçlarının değerlendirilmesi. 
ANKEM Derg. 2018;32(2):72-7.

3. European Centre for Disease Prevention and Control HIV/AIDS surveillance in Europe 2014. [erişim 28.05.2019]. https://ecdc.europa.eu/en/ publications-data/hivaids-surveillance-europe-2014

4. Gürkan Y, Toyran A, Akssoy A, Coşkun FA, Sezer A. Ankara Numune Eğitim ve Araştırma Hastanesi'ne başvuran hastaların ve kan donörlerinin hepatit ve HIV Seroprevalansının Belirlenmesi ve Anti-HCV Pozitif Hastaların HCV RNA Seviyelerinin Değerlendirilmesi. Viral Hepatit Derg. 2013;19(3):131-5. https://doi.org/10.4274/Vhd.20592

5. HIV and AIDS Activities: HIV Testing, US Food and Drug Administration. https://www.fda.gov/forpatients/ illness/hivaids/default.htm [erişim 10.03.2019].

6. Keklioğlu M, Çelebi I. İnsan Bağışıklık Noksanlığı Enfeksiyonu (HIV). The Merck Manual Tani Tedavi EI Kitabı, Cilt 1, Sayfa 77-85, Nobel Tip Kitabevi, Istanbul (1995).

7. Köse Ş, Ersan G, Liv F. Six-year analysis of the seropositivity of HBV, HCV, HIV, and syphilis in volunteer blood donors attending our blood center. Viral Hepatitis Journal. 2015;21(1):28-30.

https://doi.org/10.4274/vhd.42243

8. Malhan S, Ünal S. HIV\&AIDS Farkındalık Raporu. Ankara, (2017).

9. Şanar L. Kan donörlerinde HBsAg, anti-HCV ve antiHIV seroprevelansı: 6 yıllık bir çalışma. Ortadoğu
Medical Journal. 2016;8(2):88-93.

10. T.C. Sağlık Bakanlığı, Halk Sağlığı Genel Müdürlüğü [internet]. HIV-AIDS İstatistik [erişim: 10.03.2019] https://hsgm.saglik.gov.tr/tr/bulasicihastaliklar/862-hiv-aids/1135-h\%C4\%B1v-aidsistatislik.html

11. T.C. Sağlık Bakanlığı, Halk Sağ lığı Genel Müdürlüğü. HIV/AIDS Tanı Klavuzu. Ankara, (2018).

12. UNAIDS Data 2017, Geneva: Joint United Nations Programme on HIV/AIDS (UNAIDS). [erişim 28.05.2019]. https://www.unaids.org/en/resources/ documents/2017/2017_data_book

13. WHO and HIV/AIDS. Geneva: World Health Organization. [İnternet]. [erişim 10.03.2019]. http:// www.who.int/hiv/en

14. WHO, HIV/AIDS: Data\&Statics. https://www.who. int/hiv/data/en/ (erişim: 21 Ocak 2019).

15. Yuksel P, Saribas S, Kuskucu M, et al. Problems encountered in conventional HIV $1 / 2$ Algorithms: lack of necessity for immunoblot assays to confirm repeated ELISA reactive results. Afri Health Sci. 2018;18(2):407-16. https://doi.org/10.4314/ahs.v18i2.26

16. Yüksel $\mathrm{P}$, Ziver $\mathrm{T}$, İzmirli $\mathrm{S}$ ve ark. Anti-HIV-pozitif hastalarda doğrulama testi sonuçları: beş yıllık verilerin irdelenmesi. Klimik Derg. 2010;23(2):51-4. https://doi.org/10.5152/kd.2010.16 